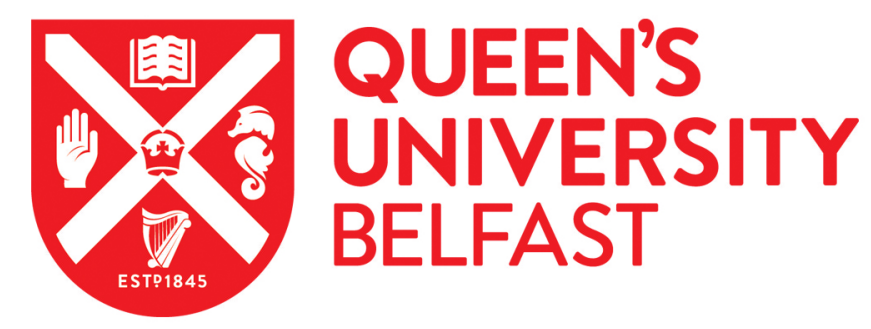

\title{
'Plugging the Gap': Shared Education and the promotion of community relations through schools in Northern Ireland
}

Hughes, J., \& Loader, R. (2015). 'Plugging the Gap': Shared Education and the promotion of community relations through schools in Northern Ireland. British Educational Research Journal, 41(6), 1125-1142. https://doi.org/10.1002/berj.3206

Published in:

British Educational Research Journal

Document Version:

Peer reviewed version

Queen's University Belfast - Research Portal:

Link to publication record in Queen's University Belfast Research Portal

\section{Publisher rights}

(C) 2015 British Educational Research Association

This is the peer reviewed version of the following article: Hughes, J. and Loader, R. (2015), 'Plugging the gap': shared education and the promotion of community relations through schools in Northern Ireland. British Educational Research Journal, 41: 1142-1155. , which has been published in final form at http://onlinelibrary.wiley.com/doi/10.1002/berj.3206/abstract. This article may be used for non-commercial purposes in accordance with Wiley Terms and Conditions for Self-Archiving.

\section{General rights}

Copyright for the publications made accessible via the Queen's University Belfast Research Portal is retained by the author(s) and / or other copyright owners and it is a condition of accessing these publications that users recognise and abide by the legal requirements associated with these rights.

\section{Take down policy}

The Research Portal is Queen's institutional repository that provides access to Queen's research output. Every effort has been made to ensure that content in the Research Portal does not infringe any person's rights, or applicable UK laws. If you discover content in the Research Portal that you believe breaches copyright or violates any law, please contact openaccess@qub.ac.uk. 
'Plugging the Gap': Shared Education and the promotion of community relations through schools in Northern Ireland

Joanne Hughes and Rebecca Loader

Author contact details:

Professor Joanne Hughes

Director of the Centre for Shared Education

School of Education

Queen's University Belfast

69/71 University Street

Belfast BT7 $1 \mathrm{HL}$

Northern Ireland

Tel: +02890975934

http://www.qub.ac.uk/research-centres/CentreforSharedEducation/

Dr Rebecca Loader

Research Associate

School of Education

Queen's University Belfast

69/71 University Street

Belfast BT7 $1 \mathrm{HL}$

Northern Ireland

Tel: +02890365131 
Although there is no consensus amongst educationalists as to the role schools play as drivers of hostilities in divided societies, there is broad agreement that they can facilitate more positive intergroup relations. In Northern Ireland the promotion of school based inter-group contact has been offered as a means through which this can happen. Until 2007, the approach was twofold, reflected on the one hand in short-term contact opportunities for pupils in predominantly Catholic and Protestant schools, and on the other, in support for integrated schools which educate Catholics and Protestants together. In 2007 the Shared Education Programme was introduced to 'bridge the gap' between short-term opportunities for contact, and 'full immersion' integrated schools. Informed by contact theory, shared education offers curriculum based interaction between pupils attending all school types, aimed at promoting the type of contact likely to reduce negative social attitudes and ultimately contribute to social harmony. In this paper, we examine the impact of shared education thus far. Our analysis suggests that whilst shared education is generally effective in promoting positive assessments of other group members, there is a danger that programme impact may be inhibited by the foregrounding of educational over reconciliation priorities. Appreciating that the downplaying reconciliation objectives may have been necessary when the programme was established in order to maximize recruitment to it, we argue that if the full potential of shared education is to be realized, moving forward, it is important for schools to engage with issues of group differences. 


\section{Background}

The education system in Northern Ireland is distinguishable by the degree of separation that exists between the Catholic and Protestant faith communities. Currently, around $93 \%$ of pupils attend predominantly 'own' religion schools, with less than 3\% Protestants attending Catholic Maintained primary and post-primary schools, and less than 6\% Catholics attending State Controlled Protestant schools. The introduction of integrated education in the early 1980s, where Catholics and Protestants are educated together, has done little to reverse the trend with such schools accounting for only $6 \%$ of overall provision (Department of Education (Northern Ireland), 2014). Since the 1970s, and in the context of a protracted conflict, the education system in Northern Ireland has been widely scrutinized with many pointing to a relationship between ethno-religious division at school and on-going hostilities between the Catholic and Protestant communities (Dunn, 1990; Hughes, 2011). Dissenting voices have however argued for the right of parents to opt for a faith-based education for their children and a prominent Catholic Bishop recently described faith schools as a "hallmark of a stable and pluralist society" (BBC News, 2010). The tension inherent in these positions reflects wider debates about the role of separate schools in promoting or exacerbating inter-group tensions, against the value of such schools as an expression of equality and respect for diversity in divided or pluralist societies (Berkeley, 2008; Gallagher, 2004; Grace, 2003; Short, 2003). Those in favour of separate education argue that faith schools contribute to the common good because they provide children with a moral and religious framework that engenders confidence in their own identity and helps them to be respectful of the beliefs and values of others (Halstead and McLaughlin, 2005; Hewer, 2001). Opponents make the case that separate education threatens social cohesion because the very separation of pupils on the grounds of faith (which may entail, by extension, separation along ethnic and cultural lines) and the teaching of distinctive norms and values can lead to a fragmentation of society (Dwyer and Parutis, 2012; Jackson, 2003; Judge, 2001; Short, 2003).

Somewhat surprisingly, given the volume of polemic generated by the existence of separate education in Northern Ireland, relatively few research studies have examined the relationship between schools and inter-group relations. Of those that have, most have suggested that separate schools contribute to community division by engendering and reinforcing stereotypes (Murray, 1985; Brocklehurst, 2006; Hughes, 2011). Murray's seminal ethnographic study, undertaken in a controlled (Protestant) and maintained (Catholic) school, 
led him to conclude that,'...segregating children of school age may actually institutionalise perceived differences between them and encourage them to formulate antipathetical stereotypes....If behaviour may be structured, or at least influenced, by such stereotypes, then the argument that segregated schooling may positively contribute to subsequent community division and conflict is strengthened' (Murray, 1985, p.104). Hughes's (2011) research, drawing on data from a qualitative study of pupils attending a Controlled post-primary school in a rural and predominantly Protestant area found that most children had very limited or only superficial contact with Catholics, and pointed to a relationship between social and physical isolation from Catholics and feelings of suspicion and fear towards them.

Although the causal connection between education and division remains moot, the value of increasing contact between Catholic and Protestant pupils has always been recognized and for many years government in Northern Ireland has sought to improve community relations though contact initiatives. From the mid-1980s onwards crosscommunity contact schemes offered opportunities for pupils within the separate sectors to come together, generally for short term extra-curricular activities (For a review of initiatives see Gallagher, 2004, 2005a). While central funding for the flagship contact scheme, the Schools Community Relations Programme, ended in 2010, existing projects continue on a largely informal basis. Alongside contact schemes, support has been provided through legislation for the establishment of new integrated schools and the transformation of existing 'separate' schools to integrated status (1989 Education Reform Order). Research into integrated schools has generally been positive in respect of their potential to promote more harmonious relations (Hayes, McAlister and Dowds, 2013, 2007; McGlynn et al., 2004; Stringer et al., 2009, 2000), although the sector remains small. Evaluations of short-term inter-school interventions, on the other hand, have generally been critical, highlighting the light touch approach to cross-community contact and the failure of many schools to engage in a meaningful way with issues of division and conflict through the curriculum (Smith and Robinson, 1996; O’Connor, Hartop and McCully, 2002; Richardson, 2011).

Frustrated with the apparent inefficacy of statutory provision for community relations in separate schools, but aware that structural reform to the largely divided education system was unlikely in the short- or medium-term, a group of educationalists led by Professor Tony Gallagher, began, in 2006, to formulate an alternative approach to addressing division via the education system. They aimed to develop a programme that could 
offer the intensity of contact experience likely to be more effective in promoting more positive social attitudes and behaviours than one-off, short-term initiatives. In 2007, the Sharing Education Programme (SEP) was launched. Underpinned by reconciliation objectives, a key programme aim is to facilitate a level of sustained, curriculum-based contact between separate schools that can ultimately help bring about a more cohesive society. In the context of existent provision, SEP represents an alternative to "full immersion" integrated education and short-term opportunities for inter-school contact.

Unlike previous initiatives, where the focus has been exclusively on reconciliation objectives, SEP encourages participating schools to devise projects that foreground other shared educational priorities. Moreover, as it does not require structural change in the school system, SEP does not impinge on parents' wishes to educate their children within a particular faith tradition. As a result, the programme is able to secure support from those parents (as well as political and religious organisations) who might be opposed the compulsory integration of schools. This may be especially advantageous in highly divided societies - and particularly in regions experiencing or emerging from conflict, like Northern Ireland (as well as Israel-Palestine and the countries of the former Yugoslavia, in which SEP has attracted some interest) - where perceived threats to cultural and religious identity can provoke significant concern and opposition.

Theory on inter-group relations, drawn primarily from the discipline of social psychology offers a strong rationale for the Shared Education Programme, and there is now a considerable body of internationally generated evidence that affirms sustained cross-group encounter as a means of reducing prejudice and facilitating mutual understanding. For example, in research undertaken with young people in countries with such diverse histories as South Africa, Norway and Israel, the amount and quality of interaction (both in-school and out-of school) between members of different groups has been associated with more positive attitudes towards the other group as a whole (Bratt, 2002; Holtman et al., 2005; Gaunt, 2011).

\section{Contact theory}

Gordon Allport (1954) is generally credited with being the first to expound the value of intergroup contact in reducing hostility and improving inter-group relations. He proposed what has become known as the 'contact hypothesis', suggesting that contact with a member of a different ethnic or racial group should facilitate more positive attitudes towards that group 
as a whole, particularly in the presence of four interrelated conditions. Firstly, groups involved in contact should have equal status. Secondly, they should work on a problem or task and share this as a common goal, sometimes called a superordinate goal. Thirdly, the task must be structured so that individual members of both groups are dependent on each other to achieve this common goal. Finally, contact should be legitimized through institutional support. Research work on inter-group contact has generally been confirmatory of these conditions, though many additional supporting variables have been proposed in the decades following the publication of Allport's theory, leading some to argue that the focus on prerequisites has the potential to render contact theory meaningless in respect of 'real world' situations (see Dixon and Durrheim, 2003). Reflecting this critique, more recent research has focused on understanding the processes through which intergroup contact leads to positive attitudinal change (see Dovidio et al., 2003; Pettigrew, 1998; Pettigrew \& Tropp, 2006; Voci \& Hewstone, 2003).

A range of change mechanisms have been proposed to explain how intergroup contact reduces prejudice. Pettigrew (1998) identifies these as: learning about the outgroup, changing behaviour, generating affective ties, and in-group reappraisal. In a similar vein, Dovidio et al. (2003) categorize mediating or change processes as relating to functional relations, behavioural factors, affective factors and cognitive factors. 'Functional relations' refers to the nature of the engagement between members of diverse groups during the contact encounter. Working together towards the achievement of a shared goal, the achievement of which is only possible through inter-group collaboration, is seen as having a positive, reinforcing effect. The fact that this achievement is shared with members of the other group increases attraction towards them, therein reducing prejudice. Affective factors are associated with the role of emotion in intergroup contact and have received increasing attention in recent years (Tropp and Pettigrew, 2004, 2005; Pettigrew and Tropp, 2008). Stephan \& Stephan (1985) note that relations between members of different ethnic groups are often imbued with anxiety. Feelings of anxiety can then prime responses towards other groups, confirming or reinforcing stereotypes and promoting distrust. Reducing intergroup anxiety through contact has been shown to reduce intergroup bias, improve outgroup attitudes and promote more positive behavioural intentions (Islam \& Hewstone, 1993; Paolini et al., 2004; Hutchison and Rosenthal, 2011). Contact has also been shown to enhance empathy towards the outgroup by the opportunity it offers for perspective-taking. 
This relates to the potential the contact experience to facilitate understanding of how it might feel to be a member of the other group (Stephan et al., 2005). Finally, cognitive factors relate to the opportunity for new learning about the outgroup that can have important positive consequences for intergroup relations (Pettigrew, 1998). Acquiring new information is seen as effective because it can reduce the likelihood of contact avoidance and feelings of discomfort in the contact situation, and it can lead to a reassessment and undermining of outgroup stereotypes and ingroup bias by increasing understanding of injustice and discrimination (Dovidio et al., 2003). In relation to cognitive factors, the mechanisms through which new knowledge is gained are seen to be a potentially important determinant of outcome. Interactions between members of opposing groups that comprise some degree of self- disclosure seem to be particularly effective in the development of improved interpersonal relations (Kenworthy et al., 2005). This finding suggests an important dynamic between cognitive and affective processes. Hence, in the case of self-disclosure, prejudice reduction might be explained by increased familiarity and concomitant anxiety reduction. It might also be the case that self-disclosure accounts for improved attitudes because the nature of imparting personal information implies that a level of trust, typically reserved for friends, has been established (Petty \& Mirels, 1981). Hence, personalised interaction and the development of cross-group friendship are deemed to play a critical role in the way that contact reduces bias (Pettigrew, 1997).

An important issue running through contact literature is the extent to which positive experiences of contact with some members of the outgroup and associated prejudice reduction can be generalized and extended to the outgroup as a whole. In order to maximize generalization potential, a number of approaches have been proposed by contact theorists, including minimizing group salience during contact (Brewer and Miller, 1984); making group salience high during contact (Johnston and Hewstone, 1992) and creating a common ingroup identity (Gaertner et al., 1993). Each of these approaches is seen to have advantages and disadvantages depending on the stage at which contact takes place. In recognition of this Pettigrew (1998) has developed an integrated approach that connects these three approaches to points in the contact encounter. According to his model, the early stages of contact should be characterized by 'decategorisation' - where group identities are played down so as to reduce anxiety and promote interpersonal liking. As participants become more comfortable with each other, group identities should become more salient in 
order that positive contact effects can be generalized to the outgroup as a whole. Finally, there is a recategorisation stage where participants' group identities are moderated to include a superordinate and cross-cutting category that all participants can claim association to - therein deemphasizing us and them categories and creating a new 'we' category. Although Pettigrew's model is helpful, there is little in the contact literature to suggest how group difference should be addressed in practice during intergroup encounters. This is an issue that we will pick up towards the end of this paper in the context of the SEP objective to promote reconciliation.

\section{Evaluation of the Shared Education Programme (SEP)}

SEP was first established in 12 partnerships based in specialist schools (majoring in ICT, languages, arts etc), which collaborated on a cross-community basis to share classes and activities in order to improve education outcomes for pupils. The programme has a curriculum focus but, because it is offered on a cross-community basis, has intended reconciliation benefits for participants, teachers, parents and, in the long term, the wider community. The Programme is delivered through three providers: Queen's University, the North Eastern Education and Library Board, and Fermanagh Trust. Recent figures estimate that 150 schools have participated to date, involving 15,000 pupils across Northern Ireland (Knox, 2013). Typical activities undertaken by schools include year 14 students completing ' $A$ ' level subjects in cross-community classes, year 12 students completing GCSE subjects in cross-community classes, and students undertaking accredited vocational training courses across both phases (14-16 and 16-19). Overall, the Sharing Education Programme represents an investment by external funders (the International Fund for Ireland and Atlantic Philanthropies) of over $£ 10.5 \mathrm{~m}$.

\section{Evidence of effectiveness}

A body of evidence is accumulating that is consistent in finding that the SEP model offers an effective means of promoting more positive inter-group evaluations. A large scale research project led by the first author of this paper, compared the SEP initiative with other forms of cross-sectoral contact in schools across Northern Ireland and found that the curriculum based focus of the programme ensured that contact was regular and sustained throughout the school year (Hughes et al, 2010). Employing a quasi-experimental design, which 
matched samples of pupils involved in SEP with non-participants from the same schools to examine contact outcomes, the study found that participation in SEP was associated with a reduction in ingroup bias; greater out-group trust; reduced anxiety towards the outgroup; more positive feelings when in the company of outgroup members; and more positive outgroup action tendencies (e.g. desire to seek contact, help out, to support, to find out more) (Hughes et al, 2010). The research also showed that key moderating variables (the factors that explain positive outcomes) were increased number of cross-group friendships and reduced intergroup anxiety (see figure $1^{1}$ ).

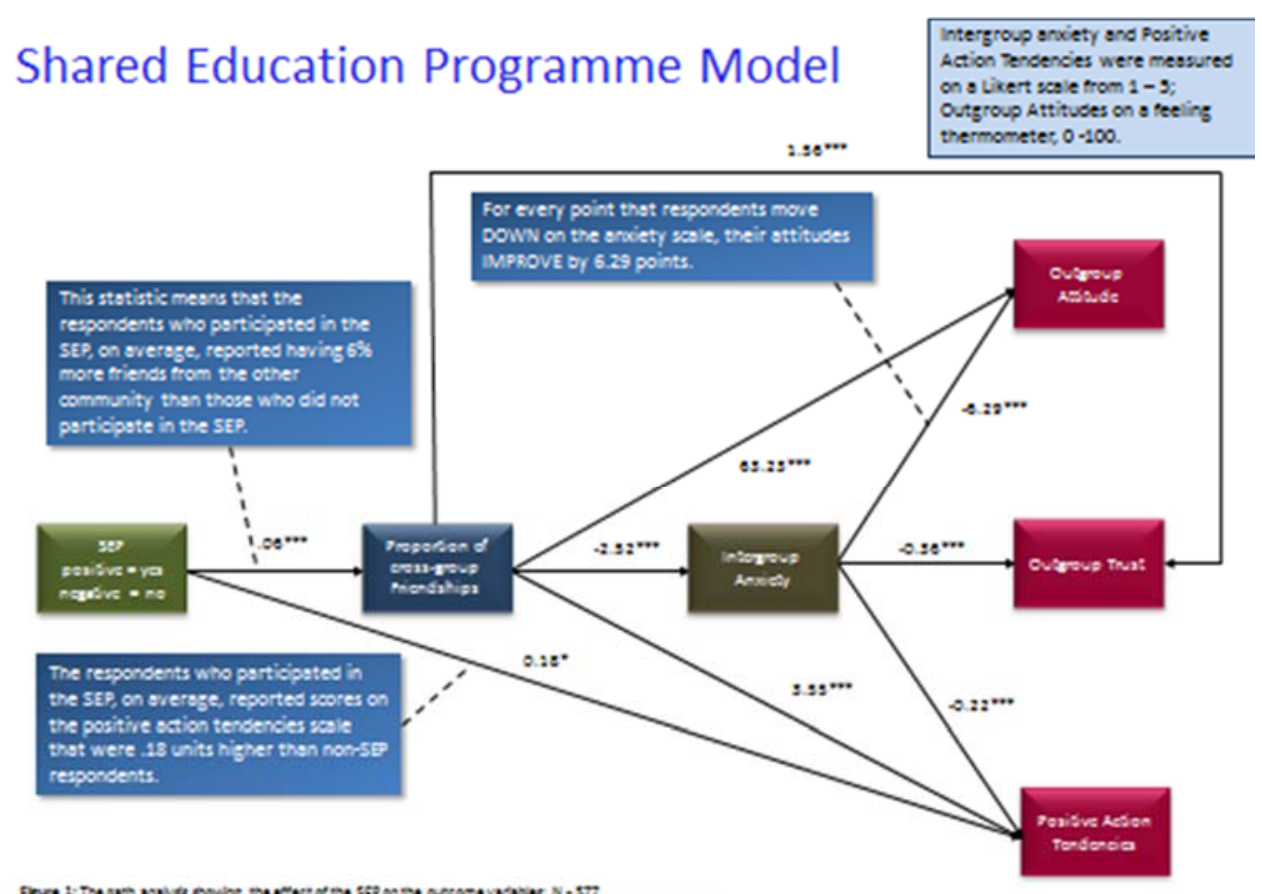

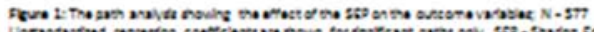

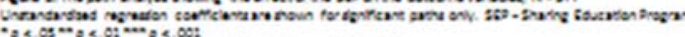

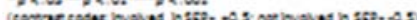

Research has also found that the environment and socio-political context within which a particular school is situated informs the nature of intergroup responses and interactions. Hence, pupils in those 'SEP schools' which were located in areas that are recognised as more divided were less likely to indicate that they had friends or were comfortable with the other community than those pupils who attended SEP schools in less divided areas. Importantly though, even where the context was recognised as divided, pupils attending SEP schools were more likely than those in non SEP schools in non-divided contexts to view the 'out'-

\footnotetext{
${ }^{1}$ This figure has previously been published in Hughes et al (2010)
} 
group positively (Hughes, et al, 2010). A more recent quantitative analysis also finds that participants in shared education in receipt of free school meals, although showing less bias than peers not participating in the programme, generally score lower on a range of contact outcomes than SEP participants who are not in receipt of free school meals, even when levels of contact are similar (Hughes, Blaylock and Donnelly, in press). In other words, pupils in more divided communities and from lower socio-economic groups who engage in contact report less positive attitudes and experiences than others not in these categories.

Other studies also offer positive findings. Duffy and Gallagher (2015) found that pupils involved in a shared education initiative in Londonderry/Derry reported a greater number of friends from the other community and in some cases these friendships extended beyond the school setting or were continued through social media. Participation in the programme was also found to promote new skills and increase levels of confidence (FGS McClure Waters, 2009). Those involved in the delivery of SEP have also been positive about its impact: a qualitative study of teachers, found that whilst there were hurdles to overcome in establishing and running shared classes, the value of the Programme is significant because it 'renders denominational school boundaries as porous' (Knox, 2010).

In order to understand the positive outcomes associated with SEP, it is important to consider the current policy context. First, a recent strategic review of education in Northern Ireland stressed the need for greater rationalization and cost effective practice in education, pointing to the inefficiencies of current segregated school structures in the context of falling rolls and an oversupply of school places (Department of Education, 2006). Furthermore the Education Order (2006) paved the way for the Entitlement Framework, which requires that all schools must 'provide all pupils with access to a minimum number of courses at Key Stage 4 (target 24) and a minimum number of courses at post-16 (target 27)' Department of Education (Circular 2009/08: http://www.deni.gov.uk/ef guidance 2009-08.pdf). Guidance from the Department of Education (Circular 2005/18: http://www.deni.gov.uk/2005 18entitlement framework-initial guidance.pdf) suggests that schools should consider a number of approaches to fulfilling the 24/27 target, including 'co-operation and collaboration with neighbouring schools, Further Education Colleges or other providers'. Second, shared education was prioritized in the most recent NI Executive Programme for Government (20112015) which outlined a commitment that every pupil should have some experience of shared education by 2015 . Consistent with this and in the context of fiscal constraint, four local 
political parties have endorsed shared education as a mechanism for both building the peace, and addressing the need for rationalization (Knox, 2010).

The fact that SEP objectives are consistent with policy directives for schools may help explain why so many have embraced the programme. Unlike other contact initiatives that are often resource-intensive and perceived as achieving little in respect of educational targets, there are tangible associated benefits to be gained from participation in SEP - in particular the extension of subject choice for pupils. Although there is no policy imperative from the Department of Education for schools to co-operate on an inter-sectoral basis in the delivery of the entitlement framework, there can be little doubt that the funding associated with SEP also provides a strong rationale for some schools to do so. Other factors that may contribute to extensive programme uptake are likely to relate to the role of teachers and to the optimal contact conditions that derive from the programme. In respect of teachers, research by Donnelly (2008) has shown that there is often a degree of resistance to dealing with controversial issues, which has been associated with the absence of appropriate training and with teachers' perceptions of their professional identity and remit. In foregrounding educational objectives, SEP encourages the involvement of teachers who, for ideological reasons, might not normally volunteer to participate in 'community relations' work. In respect of contact theory, it could be argued that inherent in the SEP initiative are conditions for contact that are widely agreed as germane to more positive out group attitudes. Hence, extending curricular choice can be seen as a superordinate goal that schools can only achieve through working collaboratively, while the nature of the intervention facilitates sustained contact that allows participants to develop the type of friendship relationship associated with reduced anxiety, prejudice reduction, trust-building and perspective-taking. SEP, because it is curriculum-based, also requires considerably more commitment from schools than short term, one-off projects. Hence, for the initiative to work, a high degree of institutional support is required. Finally, by dint of the fact that schools are separated on ethno-religious grounds, identity is salient (or prominent), not least in the form of the uniforms worn by children who move between schools.

However, whilst the general picture in relation to sharing education is a positive one, qualitative studies of SEP have highlighted barriers to effective contact, underlining the need to constantly critique the relationship between the more positive responses to others engendered by contact and the wider community benefits envisaged by the Programme. One 
study by Hughes (2014) showed that pupils in a more mixed community found it easier to make and sustain intergroup friendships than pupils from a community divided by ongoing tensions between adjacent Catholic and Protestant neighbourhoods. Reticence towards the other in the divided community context was explained with reference to the struggle experienced by pupils in reconciling school-based norms regarding the 'other' (mutual respect, friendship, tolerance, understanding, reconciliation etc) and those valorised by the local community (fear, suspicion and hostility). Moreover, a persistent finding in qualitative studies of school based contact, including that experienced by pupils in shared education initiatives, is the reluctance of some students and staff to engage with issues of difference (Donnelly 2008; Hughes, 2014).

The tendency to avoid politically sensitive issues in mixed settings is well-documented: as Donnelly $(2004$, p12) observes, 'It is deemed 'socially gauche' to be completely open about one's political or cultural views in mixed-religion company'. Both Hughes (2014) and Loader (2015), in qualitative studies of shared education, note the existence of a hierarchy of taboo subjects, with religious and some cultural issues seen as less controversial than political and social issues relating to perceived inequalities between Catholics and Protestants. Perhaps more worrying is the evidence which suggests that the expression of, or engagement with, different political perspectives in the school context can be framed as 'controversial', 'sectarian' or 'bigoted' (Donnelly, 2008; McEvoy, McEvoy and McConnachie, 2006; Emerson, 2012). In her study of two shared education partnerships, Loader (2015) observed that pupils, anxious not to be perceived as 'sectarian', were reluctant even to acknowledge the existence of difference during interviews and, instead, were often at pains to emphasise the similarities between themselves and their counterparts from the other group. Comments like "they're exactly the same as us" and "there's not one bit of difference between either of you" were fairly common, even where the preceding conversation had touched on potentially divisive issues like the constitutional status of Northern Ireland. Moreover, some pupils suggested that a more widespread belief in the relative unimportance of cultural and religious difference was a desirable outcome of shared education, and perhaps part of its intended purpose - a perspective perhaps reinforced by the provision of few opportunities to engage with difference during shared classes.

Shared education, and the theory that underpins it, places emphasis on the facilitation of cooperative and harmonious encounters, and, as shown by the quantitative 
research reported earlier, there is little doubt that attitudes towards the out group do become more positive as a consequence of participation. However, the challenge faced by shared education is to ensure that the nature of the encounters does not, intentionally or unintentionally, suppress the exploration and critique of differences in identity and experience. By failing to engage meaningfully with such matters, programmes like SEP may leave intact the institutional, social and political structures that can perpetuate discrimination and disadvantage, particularly in contexts that are already characterised by asymmetries of power and status between groups (see Abu-Nimer, 2004; Nagda and Derr, 2004; Dixon, Durrheim and Tredoux, 2005). The problem is exacerbated in Northern Ireland where cleavages in the education system are reflected not only in faith orientation but also in social class ${ }^{2}$, leading the Ministerial Advisory Group on Shared Education to recommend that the objectives of shared education to foster social integration can only be achieved within a more fully egalitarian system of post-primary education (Connolly, Purvis and O’Grady, 2013).

It has long been recognised in Northern Ireland that a risk in not dealing with difference is that those with whom we engage can be seen as exceptions to the rules that are applied to the group they are associated with. The statement, 'some of my best friends are Catholic/Protestant...' followed by a 'but', and a positive endorsement, 'they are really nice', is a commonly repeated parody for the type of relationships between individual Catholics and Protestants that allow the preservation of hostile attitudes towards the outgroup. Even where positive attitudes are generalised to the group as a whole, as studies of SEP have indicated they are, some research has suggested that contact - particularly that which focuses on similarities (and avoids matters of contention) - can have an ironic 'sedative' effect on the political attitudes of disadvantaged groups (Dixon et al., 2013). In particular, such contact may reduce perceptions of injustice among minority group members and decrease their likelihood of engaging in collective action to improve their situation (Wright and Lubensky, 2009; Dixon et al, 2012, 2013). Acknowledging this apparent tension between prejudice reduction approaches, with their emphasis on

\footnotetext{
${ }^{2}$ Currently children in both Catholic and Protestant primary schools undertake an unregulated test at the age of 10 or 11 which determines whether they attend a Grammar or Secondary School. Children attending secondary schools are significantly more likely to be in receipt of Free School Meals and are less likely to achieve the basis standard of 5 GCSEs ( $\left.A^{*}-C\right)$ at age 16 (Connolly, Purvis and O'Grady, 2013).
} 
harmony and commonality, and collective action approaches, which require attention to intergroup differences, Dixon et al. (2012) have begun to ask whether and how goals of intergroup harmony and social justice can be reconciled. Moreover, recognizing that favourable affective attitudes towards the outgroup can coexist with an absence of political opposition to inequality, the same authors have questioned whether negative evaluations are necessarily the cognitive and affective hallmarks of discrimination.

As noted above, a key feature of the promotion and delivery of the Shared Education Programme has been the foregrounding of educational objectives over reconciliation objectives. For the reasons outlined, it is likely that this dimension of the programme has contributed to its effectiveness in generating widespread participation from schools. However, reflecting the concerns of Dixon, and cognisant of findings from the qualitative research discussed above, there may be a danger of assuming that mere participation in the programme is enough to generate the type of inter-group awareness and meaningful engagement that will ultimately lead to social change. Moving forward, as shared education embeds in Northern Ireland, and as the learning transfers to other divided jurisdictions (based on the Northern Ireland model there are now shared education initiatives in Macedonia and Israel), a key challenge is how the programme can begin to synthesize the playing down of reconciliation priorities to effect maximum participation in the Programme, and the need to ensure that there is the genuine engagement with difference necessary to transform how participants think, act and respond to the other group.

Arguably the issue may be one of timing, in the early days of shared education many school principals and teachers were apprehensive about the community relations dimension of the programme, fearing the response of parents and the potential for increasing sectarian tensions in schools and their localities (Hughes et al. 2010). Hence, foregrounding the educational benefits, and minimizing the reconciliation focus mitigated anxiety and ultimately served to maximize participation. For the most part initial fears have not been realized, and Catholic and Protestant pupils sharing the same classroom no longer excites controversy in Northern Ireland. Reflecting on Pettigrew's model, which advocates a staged approach to dealing with identity differences, and taking up Dixon's observation that positive outgroup evaluations might sedate a drive to challenge inequality and 
discrimination, we would suggest that perhaps the time has come to be more intentional about reconciliation objectives.

\section{References}

Abu-Nimer, M. (2004) 'Education for coexistence and Arab-Jewish Encounters in Israel: potential and challenges,' Journal of Social Issues, 60(2), pp.405-422.

BBC News (2010) 'Catholic Church reacts to Robinson remarks on education' [online]. Available at: http://www.bbc.co.uk/news/uk-northern-ireland-11558249 (Accessed 2 February 2015).

Berkeley, R. (2008) Right to divide? Faith schools and community cohesion. London: Runnymede Trust.

Bratt, C. (2002) 'Contact and attitudes between ethnic groups: a survey-based study of adolescents in Norway', Acta Sociologica, 45(2), pp.107-125.

Brewer, M.B. and Miller, N. (1984) 'Beyond the contact hypothesis: theoretical perspectives on desegregation', in Miller, N. and Brewer, M. (eds.) Groups in contact: the psychology of desegregation. Orlando, FL: Academic Press, pp.281-302.

Brocklehurst, H. (2006) Who's afraid of children? Children, conflict and international relation. Aldershot: Ashgate.

Connolly, P., Purvis, D. and O'Grady, P.J. (2013) Advancing shared education: report of the Ministerial Advisory Group. Belfast: Queen's University.

Department of Education (2006) Schools for the future: funding, strategy, sharing: report of the Independent Strategic Review of Education. Bangor: Department of Education.

Department of Education (Northern Ireland) (2014) Schools and pupils in Northern Ireland: 1991/92 to 2013/14 [online]. Available at: 
http://www.deni.gov.uk/enrolment_time_series_updated_1314_r3.xlsx (Accessed: 2 February 2015).

Dessel, A. and Rogge, M.E. (2008) 'Evaluation of intergroup dialogue: a systematic review of the literature', Conflict Resolution Quarterly, 26(2), pp.199-239.

Dixon, J. and Durrheim, K. (2003) 'Contact and the ecology of racial division: some varieties of informal segregation', British Journal of Social Psychology, 42(1), pp.1-23.

Dixon, J., Durrheim, K. and Tredoux, C. (2005) 'Beyond the optimal contact strategy: a reality check for the contact hypothesis', American Psychologist, 60(7), pp.697-711.

Dixon, J., Durrheim, K., Kerr, P. and Thomae, M. (2013) '“What's so funny 'bout peace, love and understanding?" Further reflections on the limits of prejudice reduction as a model of social change', Journal of Social and Political Psychology, 1(1), pp.239-252.

Dixon, J., Levine, M., Reicher, S. and Durrheim, K. (2012) ‘Beyond prejudice: are negative evaluations the problem and is getting us to like one another more the solution?' Behavioural and Brain Sciences, 35(6), pp.411-425.

Donnelly, C. (2004) 'What price harmony? Teachers' methods of delivering an ethos of tolerance and respect for diversity in an integrated school in Northern Ireland', Educational Research, 46(1), pp.3-16.

Donnelly, C. (2008) 'The integrated school in a conflict society: a comparative analysis of two integrated primary schools in Northern Ireland', Cambridge Journal of Education, 38(2), pp.187-198.

Dovidio, J.F., Gaertner, S.L., and Kawakami, K. (2003). 'The contact hypothesis: the past, present, and the future', Group Processes and Intergroup Relations, 6(1), pp.5-21. 
Duffy, G. and Gallagher, T. (2015) 'Collaborative evolution: the context surrounding the formation and the effectiveness of a school partnership in a divided community in Northern Ireland', Research Papers in Education, 30(1), pp.1-24.

Dunn, S. (1990) A short history of education in Northern Ireland, 1920-1990 (Fifteenth report of the Standing Advisory Commission on Human Rights). London: HMSO.

Dwyer, C. and Parutis, V. (2012) "“Faith in the system?" State-funded faith schools in England and the contested parameters of community cohesion', Transactions of the Institute of British Geographers, 38(2), pp.267-284.

Emerson, L. (2012) 'Conflict, transition and education for "political generosity": learning from the experience of ex-combatants in Northern Ireland', Journal of Peace Education, 9(3), pp.277-295.

FGS McClure Watters (2009) The Sharing Education Programme Consultancy Report. Belfast: FGS.

Gaertner, S. L., Dovidio, J. F., Anastasio, P. A., Bachman, B. A. and Rust, M. C. (1993) 'The common ingroup identity model: recategorization and the reduction of intergroup bias', in Stroebe, W. and Hewstone, M. (eds) European Review of Social Psychology, 4, pp. 1-26.

Gallagher, T. (2004) Education in divided societies. Basingstoke: Palgrave Macmillan.

Gallagher, T. (2005) 'Faith schools and Northern Ireland: a review of research', in Gardner, R., Cairns, J. and Lawton, D. (eds.) Faith schools: consensus or conflict? London: RoutledgeFalmer, pp.156-165.

Gaunt, R. (2011) 'Effects of intergroup conflict and social contact on prejudice: the mediating role of stereotypes and evaluations', Journal of Applied Social Psychology, 41(6), pp.1340-1355. 
Grace, G. (2003) ‘Educational studies and faith-based schooling: Moving from prejudice to evidence-based argument', British Journal of Educational Studies, 51(2), pp.149-167.

Halstead, J.M. and McLaughlin, T. (2005) 'Are faith schools divisive?', in Gardner, R., Cairns, J. and Lawton, D. (eds.) Faith schools: consensus or conflict? RoutledgeFalmer, pp.61-73.

Hayes, B.C., McAllister, I. and Dowds, L. (2007) 'Integrated education, intergroup relations, and political identities in Northern Ireland', Social Problems, 54(4), pp.454-482.

Hayes, B.C., McAllister, I. and Dowds, L. (2013) 'Integrated schooling and religious tolerance in Northern Ireland', Journal of Contemporary Religion, 28(1), pp.67-78.

Hewer, C. (2001) 'Schools for Muslims', Oxford Review of Education, 27(4), pp.515-527.

Holtman, Z., Louw, J., Tredoux, C., and Carney, T. (2005) 'Prejudice and social contact in South Africa: a study of integrated schools ten years after apartheid', South African Journal of Psychology, 35(3), pp.473-493.

Hughes, J., Donnelly, C., Hewstone, M., Gallagher, T. and Carlisle, K. (2010) School partnerships and reconciliation: an evaluation of school collaboration in Northern Ireland. Belfast: Queen's University.

Hughes, J. (2011) 'Are separate schools divisive? A case study from Northern Ireland', British Educational Research Journal, 37(5), pp.829-850.

Hughes, J, Campbell, A \& Jenkins, R (2011) 'Contact, trust and social capital: A case study from Northern Ireland', Ethnic and Racial Studies, 34 (6), pp. 967-985.

Hughes, J. (2014) 'Contact and context: sharing education and building relationships in a divided society', Research Papers in Education, 29(2), pp.193-210. 
Hughes, J., Blaylock, D. and Donnelly, C. (2015) 'Does social deprivation influence inter-group contact outcomes for pupils in Northern Ireland?', Ricerche di Pedagogia e Didattica-Journal of Theories and Research in Education 10 (1), pp. 47-65

Hutchison, P. and Rosenthal, H.E.S. (2011) 'Prejudice against Muslims: anxiety as a mediator between intergroup contact and attitudes, perceived group variability and behavioural intentions', Ethnic and Racial Studies, 34(1), pp.40-61.

Islam, M.R. and Hewstone, M. (1993) 'Dimensions of contact as predictors of intergroup anxiety, perceived outgroup variability, and outgroup attitudes: an integrative model', Personality and Social Psychology Bulletin, 19(6), pp.700-710.

Jackson, R. (2003) 'Should the state fund faith based schools? A review of the arguments', British Journal of Religious Education, 25(2). pp.89-102.

Johnston, L. and Hewstone, M. (1992) 'Cognitive models of stereotype change', Journal of Experimental Social Psychology, 28(4), pp.360-386.

Judge, H. (2001) 'Faith-based schools and state funding: a partial argument', Oxford Review of Education, 27(4), pp.463-474.

Kenworthy, J., Turner, R. N., Hewstone, M. and Voci, A. (2005) 'Intergroup contact: when does it work, and why?' in Dovidio, J., Glick, P. and Rudman, L. (eds) On the nature of prejudice: fifty years after Allport. Malden, MA: Blackwell.

Knox, C. (2010) Sharing Education Programme: views from the white board. Jordanstown: Atlantic Philanthropies.

Knox, C. (2013) Shared education: a case study in policy advocacy, Conference on the Impact and Potential of Shared Education, $26^{\text {th }}-27^{\text {th }}$ June 2013, Queen's University Belfast.

Loader, R. (2015) A qualitative study of intergroup contact through shared education in Northern Ireland. Unpublished PhD thesis. Queen's University Belfast. 
McEvoy, L., McEvoy, K. and McConnachie, K. (2006) 'Reconciliation as a dirty word: conflict, community relations and education in Northern Ireland', Journal of International Affairs, 60(1), pp.81-106.

McGlynn, C., Niens, U., Cairns, E. and Hewstone, M. (2004) 'Moving out of conflict: the contribution of integrated schools in Northern Ireland to identity, attitudes, forgiveness, and reconciliation', Journal of Peace Education, 1(2), pp.147-163.

Murray, D. (1985) Worlds apart: segregated schools in Northern Ireland. Belfast: Appletree.

Nagda, B.A. and Derr, A. (2004) 'Intergroup dialogue: embracing difference and conflict, engendering community', in Stephan, W. and Vogt, P. (eds.) Education programs for improving intergroup relations: theory, practice research. New York: Teachers College Press, pp.133-151.

O'Connor, U., Hartop, B. and McCully, A. (2002) A review of the Schools Community Relations Programme. Bangor: Department of Education.

Paolini, S., Hewstone, M., Cairns, E. and Voci, A. (2004) 'Effects of direct and indirect crossgroup friendships on judgements of Catholics and Protestants in Northern Ireland: the mediating role of an anxiety-reduction mechanism', Personality and Social Psychology Bulletin, 30(6), pp.770-786.

Pettigrew T.F. (1997) 'Generalized intergroup contact effects on prejudice', Personality and Social Psychology Bulletin, 23(2), pp.173-85.

Pettigrew, T.F. (1998) 'Intergroup contact theory', Annual Review of Psychology, 49, pp.6585.

Pettigrew, T.F. and Tropp, L.R. (2006) 'A meta-analytic test of intergroup contact theory', Journal of Personality and Social Psychology, 90(5), pp.751-783. 
Pettigrew, T.F. and Tropp, L.R. (2008) 'How does intergroup contact reduce prejudice? Meta-analytic tests of three mediators', European Journal of Social Psychology, 38(6), pp.922-934.

Petty, R. E. and Mirels, H. L. (1981) 'Intimacy and scarcity: effects on interpersonal attraction for males and females', Personality and Social Psychology Bulletin, 7(3), pp.493-503.

Richardson, N. (2011) 'Evaluating the Northern Ireland experience', in Richardson, N. and Gallagher, T. (eds.) Education for diversity and mutual understanding: the experience of Northern Ireland. Oxford: Peter Lang., pp.331-351.

Ron, Y. and Maoz, I. (2013) 'Peacemaking through dialogue? Effects of intergroup dialogue on perceptions regarding the resolution of the Israeli-Palestinian conflict', Dynamics of Asymmetric Conflict, 6(1-3), pp.75-89.

Short, G. (2003) 'Faith schools and social cohesion: opening up the debate', British Journal of Religious Education, 25(2), pp.129-141.

Smith, A. and Robinson, A. (1996) Education for Mutual Understanding: The initial statutory years. Coleraine: University of Ulster.

Stephan, W.G. and Stephan, C.W. (1985) 'Intergroup anxiety', Journal of Social Issues, 41(3), pp.157-175.

Stephan, W. G., Renfro, C. L., Esses, V. M., Stephan, C. W. and Martin, T., (2005) 'The effects of feeling threatened on attitudes toward immigrants', International Journal of Intercultural Relations, 29(1), pp.1-19.

Stringer, M., Irwing, P., Giles, M., McClenahan, C., Wilson, R. and Hunter, J.A. (2009) 'Intergroup contact, friendship quality and political attitudes in integrated and segregated schools in Northern Ireland', British Journal of Educational Psychology, 79(2), pp.239-257. 
Stringer, M., Wilson, R., Irwing, P., Giles, M., McClenahan, C., and Curtis, L. (2000) The impact of schooling on the social attitudes of children. Belfast: Integrated Education Fund.

Tropp, L.R. and Pettigrew, T.F. (2004) 'Intergroup contact and the central role of affect in intergroup prejudice', in Leach, C.W. and Tiedens, L. (eds.) The social life of emotions. Cambridge: Cambridge University Press, pp.246-269.

Tropp, L. R. and Pettigrew, T. F. (2005) 'Differential relationships between intergroup contact and affective and cognitive indicators of prejudice', Personality and Social Psychology Bulletin, 31(8), pp.1145-1158.

Voci, A. and Hewstone, M. (2003) 'Intergroup contact and prejudice toward immigrants in Italy: the mediational role of anxiety and the moderational role of group salience', Group Processes and Intergroup Relations, 6(1), pp.37-54.

Wright, S.C and Lubensky, M.E. (2009) 'The struggle for social equality: collective action versus prejudice reduction', in Demoulin, S., Leyens, J.P. and Dovidio, J.F. (eds.) Intergroup misunderstandings: Impact of divergent social realities. New York: Psychology Press, pp.291-310. 